Public Inspiration: Jurnal Administrasi Publik
https://ejournal.warmadewa.ac.id/index.php/public-inspiration

\title{
Pelaksanaan Promosi Jabatan Berdasarkan Merit System Di Kabupaten Kolaka Dan Kendari Provinsi Sulawesi Tenggara
}

\author{
Abdul Sabaruddin*, Puji Prio Utomo dan Taslim Fait \\ Program Studi Administrasi Publik, Fakultas Ilmu Sosial dan Ilmu Politik, Universitas Sembilanbelas \\ November Kolaka, Indonesia
}

*Email Corespondence: abdulsabaruddin@ymail.com

How to Cite: Sabaruddin, A., Utomo, P., Fait, T. (2021). Pelaksanaan Promosi Jabatan Berdasarkan Merit System Di Kabupaten Kolaka Dan Kendari Provinsi Sulawesi Tenggara. Public Inspiration: Jurnal Administrasi Publik, 6 (2): 74-84. DOI: https://doi.org/10.22225/pi.6.2.2021.74-84

\begin{abstract}
This study aims to determine the implementation of promotion based on merit system in Kolaka and Kendari, Southeast Sulawesi. In this study, researchers applied a qualitative approach with a case study method. The employed data collection techniques were in-depth interviews and documentation. The informants in this study were 15 people selected using a purposive sampling technique. After the data were collected, they were then analyzed using an interactive model. The results showed that job promotions in the selection for the Primary High Leadership Position (Indonesian: Jabatan Pimpinan Tinggi Pratama (JPTP)) was still considered problematic in the stages of selection, including in the application, assessment, and appointment stages. At the application stage, the number of employees registering to be candidates was very low since many employees considered that the selection was conducted only to meet the procedural requirements because the official who would take up the position had already been chosen earlier. Furthermore, at the assessment and appointment stages, the selection committees were considered less objective and not transparent in scoring and determining the top 3 candidates for each position. In addition, the announcement of those top 3 (three) was only based on the alphabet of the name without any recapitulation of the score gained by each candidate.
\end{abstract}

Keyword: job promotions; merit system

\begin{abstract}
Abstrak
Penelitian ini bertujuan menganalisis pelaksanaan promosi jabatan berdasarkan merit system di Kabupaten Kolaka dan Kendari Provinsi Sulawesi Tenggara. Penelitian ini menggunakan pendekatan kualitatif dengan metode studi kasus. Tehnik pengumpulan data dilakukan dengan wawancara mendalam dan dokumentasi. Informan penelitian sebanyak 15 orang dengan pemilihan informan menggunakan teknik purposive sampling. Data yang dikumpulkan dianalisis menggunakan model interaktif. Hasil penelitian menunjukan promosi jabatan dalam pengisian jabatan pimpinan tinggi pratama (JPTP), dinilai masih bermasalah dalam tahapan seleksi meliputi tahap lamaran, tahap penilaian, dan penetapan. Pada tahap lamaran, jumlah pegawai yang melakukan pendaftaran sangat kurang karena pegawai menilai seleksi pengisian JPTP hanya untuk memenuhi syarat dan hanya dijadikan sebagai pendamping karena pejabat yang akan menduduki jabatan sudah lebih awal dipersiapkan. Kemudian tahap penilaian dan pengangkatan, pada tahap ini panitia seleksi kurang obyektif dan tidak transparan dalam pemberian bobot nilai dan penetapan 3 (tiga) nama calon pejabat. Pengumuman 3 (tiga) besar hanya berdasarkan abjad nama tanpa adanya rekapitulasi bobot nilai yang dimiliki masing-masing calon pejabat
\end{abstract}

Kata Kunci: merit system; promosi jabatan 


\section{Pendahuluan}

Promosi merupakan suatu aktivitas manajemen sumberdaya manusia yang mengalihtugaskan karyawan dari posisi suatu jabatan tertentu ke posisi jabatan yang lebih tinggi, dengan tanggungjawab yang lebih besar, tugas yang makin luas dan kompleks, serta kompensasi yang lebih baik daripada posisi jabatan sebelumnya (Suparyadi, 2015). Berdasarkan hal tersebut, penempatan aparatur sipil negara (ASN) dalam struktur pemerintahan yang professional berdasarkan merit system yang mengedepankan kompetensi dan keahlian ASN.

Desler (dalam Azhari, 2011) memaknai promosi sebagai pengangkatan pegawai negeri sipil pada jabatan lebih tinggi dalam lingkup instansi birokrasi tertentu. Promosi jabatan dalam proses manajemen sumber daya manusia, harus melihat spesifikasi jabatan yang akan di isi oleh karyawan di organisasi tersebut. Spesifikasi jabatan tersebut meliputi pendidikan, keterampilan, kepribadian dan lain-lain.

Promosi aparatur sipil negara dalam jabatan struktural dimaksudkan untuk membina karier dan kepangkatan pegawai berdasarkan syarat-syarat yang telah diatur dalam perundang-undangan. Prinsip profesionalisme yang didasarkan pada kompetensi, prestasi kerja dan jenjang pangkat serta objektif tanpa membedakan unsur SARA menjadi dasar pelaksanaan promosi tersebut (Rafi Yahya dan Dyah Mutiarin, 2015).

Pelaksanaan promosi jabatan berdasarkan merit system di Indonesia diatur dalam Undang-Undang Nomor 5 Tahun 2014 Tentang Aparatur Sipil Negara dan dijabarkan melalui Peraturan Menteri Pendayagunaan Aparatur Negara dan Reformasi Birokrasi Republik Indonesia Nomor 13 Tahun 2014 tentang Tata Cara Pengisian Jabatan Pimpinan Tinggi Secara Terbuka di Lingkungan Instansi Pemerintah.

Dalam UU Nomor 5 Tahun 2014 dijelaskan sistem merit adalah kebijakan dan manajemen ASN yang berdasarkan pada kualifikasi, kompetensi, dan kinerja, yang diberlakukan secara adil dan wajar dengan tanpa membedakan latar belakang politik, ras, warna kulit, agama dan asal usul, jenis kelamin, status pernikahan, umur, atau kondisi kecacatan. Penerapan sistem merit dimaksudkan untuk: 1) menempatkan ASN yang profesional dan berintegritas pada jabatan birokrasi pemerintah sesuai kompetensinya; 2) mempertahankan ASN melalui pemberian kompensasi yang layak; 3) mengembangkan kemampuan ASN melalui bimbingan dan diklat; dan 4) melindungi karier ASN dari diskriminasi, primordialisme dan kebijakan lainnya yang bertentangan dengan prinsip merit.

Menurut Moekjat (dalam Daniarsiyah, 2017) merit system merupakan suatu sistem kepegawaian yang didasarkan atas kecakapan dalam mengangkat pegawai. Indikator sistem merit terkait dengan rekrutmen seleksi menurut Sulardi (dalam Daniarsiyah, 2017) adalah: 1) perencanaan yang baik dan handal melalui teknik perekrutan kreatif dan agresif; 2) semua yang berpartisipasi dalam program ini harus bertanggung jawab dan didefinisikan dengan baik; 3) perekrutan melibatkan individu yang mampu dan sumber yang tepat dalam upaya untuk mendapatkan pekerja dari semua segmen masyarakat; 4) semua pelamar diperlakukan secara adil tanpa memandang latar belakang politik, ras, agama warna, asal etnis, jenis kelamin, status perkawinan, usia, atau cacat, serta mendapatkan imbalan yang sesuai untuk privasi mereka dan hak-hak konstitusional; 5) seleksi didasarkan pada kemampuan, pengetahuan, dan keahlian melalui kompetisi yang adil dan terbuka bagi semua untuk memiliki kesempatan yang sama; 6) metode seleksi dapat digunakan untuk memastikan bahwa hanya kandidat yang mampu mendapatkan pekerjaan serta penempatan mereka pada posisi yang paling tepat; 7) karyawan diterima harus dilindungi dari pilih kasih atau penipuan pada tujuan politik. Proses rekrutmen berdasarkan prestasi menurut Haider dan Huma (2019) terdiri dari tiga fase yakni (1) application; yakni terkait kebijakan proses rekrutmen sebagai bentuk transparansi berupa pengumuman lowongan, (2.) assessment and selection: mencakup kerangka kompetensi dengan kriteria penilaian yang ditentukan yang digunakan untuk mengevaluasi kandidat dalam kaitannya dengan pekerjaan, dan (3) final 
appointment: fase penentuan pejabat.

Namun penerapan system merit melalui promosi jabatan di Indonesia belum sepenuhnya didasarkan pada kompetensi, aspek keadilan dan latar belakang pendidikan aparatur sipil negara (ASN). Tahun 2019, Kementerian Pendayagunaan Aparatur Negara dan Reformasi Birokrasi berdasarkan laporan kinerjanya menunjukkan bahwa indeks system merit manajemen ASN Nasional kategori kurang (sebesar 0,57 atau 81, 43\% dari target 0,71). Hasil ini diperoleh dari rata-rata indeks yang diperoleh dari instansi pemerintah pusat maupun daerah. Pemerintah daerah (provinisi, kabupaten dan kota) pelaksanaan system merit masih dalam kategori kurang (LK Kemenpan dan Reformasi Birokrasi, 2019).

Permasalahan dalam pelaksanaan reformasi birokrasi juga disampaikan Suharman (2017). Hasil penelitian Suharman (2017 ) bahwa penempatan aparatur ke dalam jabatan belum sesuai dengan kompetensi dan latar belakang pendidikan, sistem merit belum berjalan secara obyektif serta kuatnya pengaruh pejabat politik dalam penempatan jabatan struktural. Kondisi ini bertentangan dengan tujuan dari reformasi birokrasi dalam pelaksanaan promosi jabatan melalui merit system. Dimana promosi jabatan berbasis merit system akan menghapuskan ketidakadilan, subyektifitas dan balas budi politik dan melahirkan pejabat yang memiliki kompetensi dan professional dibidangnya. Seperti yang disampaikan Wibowo (dalam Yahya dan Mutiarin, 2015) bahwa pengangkatan pegawai yang menggunakan merit system mengharuskan calon yang melamar memiliki kompetensi keahlian, dan profesionalitas berdasarkan kompetensi jabatan yang akan diemban nanti. Sehingga jabatan di instansi pemerintah akan diisi aparatur sipil negara yang kompeten dan ahli dibidangnya.

Belum terlaksananya pelaksanaan promosi jabatan berdasarkan merit system juga terjadi dalam seleksi terbuka pengisian JPTP di Kabupaten Kolaka dan Kota Kendari Provinsi Sulawesi Tenggara. Proses pelaksanaan yang tidak transparan, adanya kecenderungan jabatan di masing-masing instansi diisi aparatur internal, serta penentukan pejabat struktural masih dipengaruhi kepentingan pejabat politik salah satu masalah dalam penentuan pejabat. Sehingga harapan untuk melahirkan pejabat pemerintah yang professional sesuai amanah UU Nomor Nomor 5 Tahun 2014 tidak terwujud.

Berdasarkan hal tersebut, artikel ini akan mengkaji pelaksanaan promosi jabatan berdasarkan merit system di Kabupaten Kolaka dan Kota Kendari Provinsi Sulawesi Tenggara. Konsep yang dibangun dalam penelitian ini adalah melahirkan gagasan untuk membangun reformasi birokrasi melalui seleksi pejabat secara terbuka khususnya dalam proses tahapan seleksi berdasarkan Peraturan Menteri Pendayagunaan Aparatur Negara dan Reformasi Birokrasi Republik Indonesia Nomor 13 Tahun 2014 tentang Tata Cara Pengisian Jabatan Pimpinan Tinggi Secara Terbuka di Lingkungan Instansi Pemerintah

\section{Kajian Pustaka}

\section{Reformasi Birokrasi}

Reformasi birokrasi digulirkan untuk mendorong seluruh organisasi peyelenggara pemerintahan yang masih dinilai lamban, boros, dan tidak efektif-efisien, menjadi mampu melayani dengan dukungan aparatur pemerintah yang memiliki kapabilitas memadai sehingga mampu berkinerja secara maksimal, efektif dan efisien pada proses penyelenggaraan pemerintahan. Penempatan orang-orang atau aparatur yang tepat dalam mengisi jabatan dalam struktur pemerintahan melalui merit system merupakan salah satu bentuk reformasi birokrasi. Seleksi birokrat harus mengarah kepada merit system yaitu "the right man on the right place" dan menghindari spoil system agar birokrat benar-benar dapat dan mampu memberikan pelayanan yang maksimal.

Menurut Sedarmayanti (2013:71) reformasi birokrasi adalah upaya pemerintah meningkatkan kinerja melalui berbagai cara dengan tujuan efektivitas, efisiensi, dan akuntabilitas. Reformasi birokasi dimaksudkan untuk mewujudkan pemerintahan yang baik, 
bersih, transparan dan professional, bebas korupsi, kolusi, dan nepotisme (KKN) melalui (1) penataan kelembagaan, (2) penataan ketatalaksanaan, (3) penataan sumberdaya manusia aparatur, (4) akuntabilitas, dan (5) pelayanan dan kualitas pelayanan.

Mereformasi birokrasi bukanlah sesuatu yang mudah karena harus menformat kembali konfigurasi birokrasi yang selama ini tertutup menjadi birokrasi yang terbuka dana tau birokrasi yang dilayani menjadi birokrasi yang melayani (Sabaruddin, Abdul dan Achmad Lamo Said, 2020:1). Reformasi birokrasi dalam penyelenggaraan pemerintahan dan layanan publik diarahkan untuk menciptakan kinerja birokrasi yang professional dan akuntabel (Sabaruddin dan Achmad Lamo Said, 2020:170).

Menurut Holidin (2013:vi) reformasi birokrasi dapat dikelompokkan menjadi dua bagian utama yaitu pelayanan publik dan sumberdaya aparatur. Pelayanan publik sebagai bentuk dampak perubahan reformis paling riil tetap memerlukan (1) standarisasi pelayanan yang bertumpu pada pelibatan masyarakat di dalam proses dan penilaian kinerjanya, (2) rasionalisasi penataan organisasi, (3) mengintegrasikan pelayanan perizinan bagi dunia swasta/pelaku usaha, (4) pengembangan penatalaksanaan, dan (5) aplikasi e-office. Sementara aspek sumberdaya manusia meliputi (1) rekrutmen dan promosi aparatur secara terbuka, (2) perbaikan remunerasi, (3) assessment center, (4) balance score card, (5) zona integritas menuju wilayah bebas dari korupsi (ZI-WBK).

Dalam Peraturan Presiden Nomor 81 Tahun 2010 tentang Grand Desain Reformasi Birokrasi 2010-2015, dijelaskan reformasi birokrasi bertujuan untuk menciptakan birokrasi pemerintah yang profesional dengan karakteristik adaptif, berintegritas, berkinerja tinggi, bersih dan bebas KKN, mampu melayani publik, netral, sejahtera, berdedikasi, dan memegang teguh nilai-nilai dasar dan kode etik aparatur negara. Adapun area perubahan yang menjadi tujuan reformasi birokrasi meliputi seluruh aspek manajemen pemerintahan meliputi organisasi, tata laksana, peraturan perundang-undangan, sumberdaya manusia aparatur, pegawasan, akuntabilitas, pelayanan publik, pola pikir (mid set) dan budaya kerja (culture set) aparatur.

\section{Promosi Jabatan}

Promosi merupakan suatu aktivitas manajemen sumberdaya manusia yang mengalihtugaskan karyawan dari posisi suatu jabatan tertentu ke posisi jabatan lain yang memiliki level yang lebih tinggi, dengan tanggungjawab yang lebih besar, tugas yang makin luas dan kompleks, serta kompensasi yang lebih baik daripada posisi jabatan sebelumnya (Suparyadi, 2015:137). Jadi menurut Suparyadi (2015:257) promosi jabatan selain dimaksudkan sebagai pengembangan kompetensi karyawan juga merupakan bentuk penghargaan dari organisasi atas prestasi kerja yang dicapai oleh karyawan, dan juga dalam rangka memotivasi karyawan tersebut dan karyawan lainnya agar mereka makin meningkatkan kinerjanya.

Menurut Sedarmayanti (dalam Sedarmayanti, 2017:169) promosi adalah perpindahan karyawan dari suatu jabatan ke posisi lain dengan gaji, tanggung jawab, dan/atau jenjang organisasi lebih tinggi. Dari pengertian tersebut, maka dapat dikatakan bahwa promosi jabatan memberikan peran penting bagi setiap pegawai bahkan menjadi idaman yang selalu dinanti-nantikan. Hal ini disebabkan karena dengan mendapatkan promosi, pegawai yang bersangkutan merasa diberikan kepercayaan dan pengakuan mengenai kemampuan serta kecakapan untuk menduduki suatu jabatan yang lebih tinggi. Dengan demikian, promosi tersebut akan memberikan status sosial, wewenang, tanggung jawab, serta penghasilan yang semakin besar bagi pegawai.

\section{Merit System}

Merit system merupakan dasar pertimbangan yang digunakan untuk pengangkatan atau penempatan seseorang untuk menduduki suatu jabatan tertentu yang meliputi kecakapan atau prestasi. Menurut Thoha (dalam Azhari, 2011:76) merit system merupakan 
suatu model perekrutan dimana calon yang lulus seleksi benar-benar didasarkan pada prestasi kerja, kompetensi, keahlian, kemampuan dan pengalaman. Sistem ini menekankan pada profesionalisme dan keahlian serta pengalaman yang dimiliki oleh seorang pegawai negeri sipil, sehingga apabila seorang pegawai memiliki kompetensi dan persyaratan objektif yang dimaksudkan dapat diangkat dalam jabatan tersebut. Sementara Mahmudi (2015:184) mengatakan merit system merupakan pendekatan dalam pemberian penghargaan yang didasarkan pada prestasi hasil kerja (job performance). Dalam sistem ini yang diutamakan adalah kemampuan kerja seseorang, baik berupa keterampilan, keahlian, efisiensi dan efektivitas kerjanya. Dalam memberikan penghargaan, sistem prestasi kerja tidak memandang usia atau senioritas (masa kerja) pegawai, sehingga pegawai yang masih muda (yunior) pun apabila mampu berprestasi akan dapat melampaui seniornya.

Di Indonesia, sistem merit diatur dalam Undang-Undang Nomor 5 Tahun 2014 pasal 1 ayat 22, sistem Merit adalah kebijakan dan Manajemen ASN yang berdasarkan pada kualifikasi, kompetensi, dan kinerja secara adil dan wajar dengan tanpa membedakan latar belakang politik, ras, warna kulit, agama, asal usul, jenis kelamin, status pernikahan, umur, atau kondisi kecacatan. Selanjutnya dalam Peraturan Menteri Pendayagunaan Apratur Negara dan Reformasi Birokrasi Republik Indonesia Nomor 13 Tahun 2014 tentang Tata Cara Pengisian Jabatan Pimpinan Tinggi Secara Terbuka di Lingkungan Instansi Pemerintah, dijelaskan satu dari sembilan prinsip dalam sistem merit adalah melakukan rekrutmen, seleksi dan prioritas berdasarkan kompetisi yang terbuka dan adil.

Stahl (dalam Afrianto dan Prasojo (2020:20) mengemukakan beberapa prinsip dari merit sebagai berikut:

Adequate publicity. Pemberitahuan adanya lowongan pekerjaan berikut persyaratannya harus diberitahukan kepada publik sehingga masyarakat yang berminat memiliki kesempatan untuk mengetahuinya.

Opportunity to apply. Setiap orang memiliki kesempatan yang sama untuk dapat melakukan lamaran terhadap suatu seleksi jabatan.

Realistic standards.Standar kualifikasi harus secara rasional berkaitan dengan pekerjaan yang akan diisi, dan harus berlaku secara imparsial kepada seuruh kandidat yang membuat ketertarikan mereka diketahui.

Absence of discrimination. Standar yang digunakan harus berisi faktor-faktor yang berkaitan dengan kemampuan dan kesesuaian untuk pekerjaan, bukan karena faktor di luar itu.

Ranking on the basis of ability. Esensi kompetensi mengindikasikan peringkat calon/ kandidat atas dasar evaluasi relatif akan kecakapan dan kesesuaian mereka, dan proses seleksi yang dapat berimplikasi terhadap peringkat dimaksud.

Knowledge of results. Publik harus dapat mengetahui bagaimana proses berjalan, dan setiap orang yang percaya bahwa prosesnya tidak berjalan dengan baik dalam kasus yang menyangkut dirinya, maka yang bersangkutan harus diberi kesempatan untuk melakukan tinjauan administrative.

\section{Metode}

Pendekatan dalam penelitian ini menggunakan pendekatan kualitatif dengan metode studi kasus. Menurut Sugiyono (2016) metode penelitian kualitatif digunakan pada kondisi obyek alamiah. Studi kasus tepat digunakan karena penelitian ini menyelidiki proses tahapan seleksi calon pejabat yang akan menduduki jabatan pimpinan tinggi pratama (JPTP) dan aktivitas panitia seleksi.

Untuk mendapakan informasi, pengumpulan data dilakukan melalui studi pustaka, wawancara, dan dokumen. Lokasi penelitian di Kabupaten Kolaka dan Kota Kendari 
Provinsi Sulawesi Tenggara, Indonesia dengan menggunakan teknik purposive sampling untuk menentukan informan. Informan yang terdiri dari panitia seleksi, peserta seleksi, dan dan pegawai pada organisasi perangkat daerah (OPD) yang terlibat dalam pelaksanaan promosi jabatan. Peneliti melakukan wawacara bebas (interview) secara mendalam kepada informan. Kemudian studi literatur dan dokumen dipelajari untuk memperkuat data dari wawancara.

Untuk menganalisis data penelitian, teknik yang digunakan adalah teknik analisis data kualitatif model Miles dan Huberman. Tehnik tersebut meliputi kondensi data (data condensation), penyajian data (display data), dan penarikan kesimpulan (Miles, Hubermen, dan Sardana (2014).

\section{Hasil Penelitian dan Pembahasan}

\section{Tahap Lamaran}

Kebijakan pelaksanaan seleksi untuk pengisian jabatan pimpinan tinggi secara khusus diatur dalam Undang-Undang Nomor 5 Tahun 2014 tentang Aparatur Sipil Negara khususnya pasal 108. Pada ayat 3 diisyaratkan pengisian jabatan pimpinan tinggi pratama dilakukan secara terbuka dan kompetitif di kalangan PNS dengan memperhatikan syarat kompetensi, kualifikasi, kepangkatan, pendidikan dan pelatihan, rekam jejak jabatan, dan integritas serta persyaratan lain sesuai dengan peraturan perundang-undangan. Kemudian dijelaskan dalam Peraturan Menteri Pendayagunaan Aparatur Negara dan Reformasi Birokrasi Nomor 13 Tahun 2014, bahwa dalam rangka pengisian jabatan tinggi harus pula prinsip dalam sistem merit. Menurut Nurprojo, (2014) tujuan utama dari UU ASN adalah melahirkan aparatur negara yang mempunyai independensi dan netralitas, kompetensi, kinerja/produktivitas kerja, integritas, kesejahteraan, kualitas pelayanan publik serta pengawasan dan akuntabilitas. Dengan tujuan tersebut diharapkan akan lahir SDM aparatur negara yang diimpikan dalam reformasi birokrasi.

Untuk melahirkan aparatur birokrasi tersebut, pemerintah Kabupaten Kolaka dan Kota Kendari Provinsi Sulawesi Tenggara, Indonesia menyelenggarakan promosi jabatan untuk mengisi beberapa JPTP. Rangkaian aktivitas pelaksanaan promosi jabatan melalui seleksi terbuka dalam penempatan JPTP di Kota Kendari dan Kabupaten Kolaka dimulai dengan pembentukan panitia seleksi. Panitia seleksi terdiri dari: 1) pejabat dari lingkungan instansi internal; 2) pejabat dari instansi lain yang sesuai bidang tugas jabatan yang lowong; 3) unsur akademisi/pakar/profesional. Di Kabupaten Kolaka, pelaksanaan seleksi JPTP telah dilaksanakan 3 (tiga) kali sejak tahun 2015. Hal ini sesuai dengan surat Keputusan Bupati Kolaka Nomor: 188.45/177/2015 tentang panitia seleksi terbuka jabatan pimpinan tinggi pratama dilingkungan pemerintah daerah Kabupaten Kolaka. Tahun 2016, pemerintah Kabupaten Kolaka kembali melaksanakan pengisian jabatan pimpinan tinggi pratama dengan membentuk panitia seleksi melalui keputusan bupati nomor: 188.45/050/2016 dan tahun 2017 dengan surat keputusan Bupati Nomor: 188.45/103/2017.

Formasi JPTP di Kabupaten Kolaka adalah 1) Kepala Dinas Pekerjaan Umum dan Penataan Ruang Kabupaten Kolaka; 2) Kepala Dinas Koperasi, Usaha Kecil dan Menengah Kabupaten Kolaka; 3) Kepala Dinas Ketahanan Pangan Kabupaten Kolaka; 4) Kepala Dinas Kepemudaan dan Olah Raga Kabupaten Kolaka; 5) Kepala Dinas Kesehatan Kabupaten Kolaka; 5) Kepala Dinas Komunikasi dan Informatika Kabupaten Kolaka; dan 6) Staf Ahli Bupati Bidang Ekonomi, Keuangan dan Pembangunan. Sementara di Kota Kendari pembentukan panitia seleksi berdasarkan surat Keputusan Walikota Kendari Nomor: 982 Tahun 2018 dengan formasi jabatan sekretaris daerah (Sekda), dinas lingkungan hidup, dinas pekerjaan umum dan Inspektorat.

Hasil penelitian diperoleh keterangan bahwa, panitia dalam pelaksanaan seleksi JPTP kurang memiliki pengetahuan umum mengenai penilaian kompetensi. Panitia seleksi JPTP hanya 2 (dua) orang yang berasal dari Kota Kendari yang memiliki standar tersebut. Dua 
orang ini telah mengikuti workshop peningkatan kualitas pelaksanaan seleksi terbuka yang dilaksanakan Komisi Aparatur Sipil Negara (KASN) berkerjasama dengan Australian Public Service Commission (APSC). Kemudian pelatihan traning of trainer (TOT) seleksi jabatan pimpinan tinggi. Kondisi ini menyebabkan, timbulnya perbedaan pandangan dalam menentukkan kriteria dan bobot penilaian dalam seleksi. Sementara Dalam PermenPAN RB Nomor 13 Tahun 2014 tentang Tata Cara Pengisian Jabatan Pimpinan Tinggi Secara Terbuka di Lingkungan Instansi Pemerintah dijelaskan panitia seleksi harus memiliki memiliki pengetahuan dan/atau pengalaman sesuai dengan jenis, bidang tugas dan kompetensi jabatan yang lowong; dan memiliki pengetahuan umum mengenai penilaian kompetensi.

Setelah terbentuknya panitia seleksi, tahap selanjutnya adalah tahap lamaran. Tahap ini dilakukan setelah ada rekomendasi Komisi Aparatur Sipil Negara (KASN). Tahap lamaran merupakan proses pengisian JPTP di Kabupaten Kolaka dan Kota Kendari. Untuk memudahkan calon pegawai mendaftarkan diri, panitia seleksi menyampaikan informasi melalui media (papan pengumuman, cetak dan elektronik). Pengumuman memuat formasi JPTP yang akan diisi, persyaratan pelamar, tata cara pendaftaran, dan pelaksanaan seleksi. Data yang diperoleh, pegawai yang mengikuti seleksi JPTP di Kota Kendari pada sangat kurang peminat. Tiga jabatan yang akan diseleksi yakni kepala dinas lingkungan hidup dan kehutanan, kepala dinas pekerjaan umum dan penataan ruang serta kepala inspektorat hanya dilamar 20 calon pejabat. Sementara di Kabupaten Kolaka dari 6 (enam) jabatan hanya dilamar 56 calon pejabat dan yang lolos administrasi 54 calon pejabat.

Keterangan yang diperoleh dari informan penelitian, meskipun panitia seleksi telah secara terbuka mengumumkan lowongan di media elektronik, media cetak, dan pengumuman di instansi masing-masing tetapi jumlah aparatur sipil negara yang mendaftar pada seleksi JPTP khususnya di Kota Kendari masih kurang. Kurangnya minat pegawai melakukan pendaftaran disebabkan faktor individu pegawai, yakni budaya kompetisi antar pegawai. Pejabat yang mengikuti seleksi JPTP di Kabupaten Kolaka dan Kota Kendari bertujuan hanya untuk menambah pengetahuan dan memenuhi persyaratan keberlanjutan proses seleksi, dimana setiap lowongan jabatan minimal diisi 3 (tiga) calon pejabat. Kurangnya pegawai memiliki keinginan untuk melibatkan diri bersaing dalam pelaksanaan seleksi, karena pegawai menilai seleksi JPTP hanya sebagai pemenuhan aturan karena pejabat yang akan menduduki jabatan sudah lebih awal dipersiapkan atau pejabat "titipan" dan pegawai khawatir hanya sebagai pendamping dalam pelaksanaan seleksi.

Kondisi ini menunjukkan bahwa reformasi birokrasi melalui promosi jabatan melalui seleksi terbuka JPTP belum menghilangkan aspek kedekatan baik emosional maupun politik. Kedekatan emosional seperti kedekatan kekerabatan dan organisasi kemasyarakatan. Sementara kedekatan politik seperti tim sukses pada saat pemilihan kepala daerah (Pilkada). Sehingga seseorang mendapatkan jabatan bukan karena kemampuan dan kompetensi yang dimiliki tetapi karena "politik balas jasa". Sementara reformasi birokrasi melalui promosi jabatan dimaksudkan untuk menghilangkan peran politik dalam menentukan pejabat. Penempatan pejabat harus professional yang didasarkan pada job description dan job specification yang telah ditentukan serta berpedoman prinsip "the right man in the right place and the right man behind the right job". Atau dengan kata lain, kompetensi, kualifikasi, kepangkatan, latar belakang pendidikan dan latihan, rekam jejak jabatan, serta integritas menjadi syarat penting dalam mengangkat pejabat untuk mengisi jabatan tertentu.

Hal ini sesuai pandangan Wahyudi Kumorotomo dan Ambar Widaningrum (2010) menjelaskan intevensi dan unsur subyektifitas harus dihindari dalam rekruitmen dan evaluasi manajemen SDM. Sebab intervensi terhadap birokrasi mengakibatkan tidak berjalannya tugas dan fungsinya dengan baik. Untuk menghindari hal tersebut, merit system menjadi solusi untuk menjaga sikap apolitis birokrasi dalam proses rekruitmen pegawai.

\section{Tahap Penilaian dan Pilihan}

CC-BY-SA 4.o License, Copyright 2021, Public Inspiration, ISSN 2581-2378, E-ISSN 2580-5975 
Pada tahap ini, panitia seleksi melakukan penilaian berdasarkan hasil seleksi yang dilaksanakan yakni seleksi administrasi dan seleksi kompetensi. Seleksi kompetensi terdiri dari kompetensi manajerial dengan assessment center dan seleksi kompetensi bidang meliputi persentase makalah dan wawancara Pelaksanaan assessment center panitia seleksi bekerjasama dengan tim independen BKN Makassar dan Universitas Negeri Makassar.

Tahap persentase makalah akan dinilai penguasaan materi dan kemampuan menjelaskan isi makalah. Makalah yang dibuat mencerminkan pemikiran konseptual yang memuat tentang rencana strategis yang akan dilaksanakan dan menjadi prioritas apabila menjadi JPTP sesuai jabatan yang dilamar. Penyusunan makalah didasarkan pada Visi dan Misi Wali Kota Kendari dan Bupati Kolaka. Kemudian tahap wawancara aspek yang menjadi penilaian adalah kemampuan memecahkan masalah, kemampuan sosiokultural yakni kemampuan memahami kondisi pegawai dan kultur organisasi, dan kompetensi tehnis dan non tehnis. Kemampuan tehnis berhubungan dengan hardskill yakni kemampuan spesifik yang dimiliki pegawai dan kemampuan non tehnis berhubungan soft skill, terkait dengan kemampuan beradaptasi, berkomunikasi, dan sifat kemimpinan.

Hasil penelitian, tahap ini merupakan tahap yang banyak mendapat sorotan dari calon pejabat. Pejabat yang mengikuti seleksi JPTP menilai tahap ini kurang obyektif dan transparan dalam pemberian nilai bobot atau persentase. Hasil wawancara dengan peserta seleksi, DHL menjelaskan pada tahap ini pengalaman kerja dan kemampuan spesifik tidak mendapat perhatian khusus karena besarnya nilai bobot yang diberikan sangat rendah. Pendidikan dan pelatihan yang menjadi pengalaman seseorang tidak mendapat nilai positif sementara syarat ini sangat penting dimiliki seorang pejabat untuk menduduki jabatan tertentu.

Keterangan yang disampaikan panitia seleksi, JK menjelaskan bobot nilai dan persentase dalam setiap tahap seleksi ditentukan berdasarkan kesepakatan panitia seleksi dan tidak ada sistem penilaian baku yang berdasarkan aturan. Sehingga pemberian bobot bersifat subyektif karena tidak adanya indikator tetapi berdasarkan asumsi dan pertimbangan dari panitia seleksi. Dalam Peraturan Menteri Pendayagunaan Apratur Negara dan Reformasi Birokrasi Republik Indonesia Nomor 13 Tahun 2014 tentang Tata Cara Pengisian Jabatan Pimpinan Tinggi Secara Terbuka di Lingkungan Instansi Pemerintah juga tidak memuat tentang bobot penilaian, sehingga tidak ada dasar bagi pemerintah daerah dalam menentukan skala persentase dalam setiap tahapan seleksi.

Berdasarkan keterangan tersebut, promosi jabatan berdasarkan merit system belum dilaksanakan sesuai aturan khususnya penerapan syarat kompetensi, pendidikan, dan pelatihan yang dimiliki calon pejabat. Kondisi ini juga di tambah dengan belum adanya standar baku skor bobot nilai untuk dijadikan acuan normal dalam setiap tahapan seleksi. Sehingga penetapan bobot nilai menjadi kewenangan panitia seleksi berdasarkan penafsiran masing-masing. Hal ini memberikan dampak pada proses penjaringan pejabat aparatur sipil negara yang tidak bermuara pada profesionalisme dan melahirkan pejabat yang berkompeten. Sementara syarat utama reformasi birokrasi penataan sumber daya manusia aparatur dengan penerapan merit sistem melalui promosi jabatan dilaksanakan berdasarkan prinsip profesionalisme sesuai kompetensi, prestasi kerja, jenjang kepangkatan, pendidikan dan pelatihan.

\section{Tahap Pengangkatan}

Tahap terakhir dalam proses seleksi JPTP di Kabupaten Kolaka dan Kota Kendari adalah pengangkatan. Pada tahap ini, sesuai dengan sesuai Peraturan Menteri Pendayagunaan Aparatur Negara dan Reformasi Birokrasi Nomor 13 Tahun 2014 dijelaskan panitia seleksi menyampaikan hasil penilaian jabatan tinggi pratama (setara dengan eselon IIa dan IIb) dan memilih sebanyak 3 (tiga) calon sesuai urutan nilai tertinggi untuk disampaikan kepada pejabat yang berwenang. Pejabat yang berwenang mengusulkan 3 (tiga) nama calon yang telah dipilih panitia seleksi kepada pejabat pembina kepegawaian 
(menteri/pimpinan lembaga/gubernur/bupati/walikota).

Proses penetapan tiga besar didasarkan pada pejabat yang kompeten dibidangnya masing-masing. Data yang diperoleh, pejabat yang diangkat dari hasil seleksi JPTP di Kota Kendari adalah Paminuddin, SE M. Si (Kepala Dinas Lingkungan Hidup dan Kehutanan), Mahmud Buburanda, ST., MT (Kepala Dinas Pekerjaan Umum dan Penataan Ruang), dan Syarifuddin, SE, Ak., MSA (Inspektur). Sementara jabatan sekretaris daerah (Sekda) tidak dilaksanakan seleksi karena kurangnya peminat dan belum adanya rekomendasi dari gubernur. Di Kabupaten Kolaka pejabat yang diangkat masing-masing: Ir. Dwi Dharma, M. AP (Kepala Dinas Pekerjaan Umum dan Penataan Ruang), Drs. Basir Saripa, MM (Kepala Dinas Koperasi, UKM), Suyanto, S.P., M. Si (Kepala Dinas Ketahanan Pangan), Hasbir Jaya Razak, SP, MH (Dinas Kepemudaan dan Olahraga), Drs. Harun Masirri, M. Kes (Kepala Dinas Kesehatan), Drs. I Nyoman Suastika, M. Si (Kepala Dinas Komunikasi dan Informatika), Hj. Andi Parwah, S. Sos (Staf Ahli Bupati Bidang Ekonomi, Keuangan dan Pembangunan).

Hasil penelitian, tahap ini dinilai tidak mengedepankan asas keterbukaan dalam penetapan 3 (tiga) nama calon pejabat. Pengumuman 3 (tiga) besar melalui media online dan media massa dan pengumuman resmi panitia seleksi dimasing-masing instansi hanya berdasarkan abjad nama bukan berdasarkan rekapitulasi bobot nilai yang dimiliki calon pejabat. Pada pengumuman, tidak dicantumkan bobot nilai yang diperoleh masing-masing calon pejabat, sehingga calon pejabat tidak mengetahui bobot nilai yang diperoleh saat mengikuti seleksi. Bobot nilai yang diperoleh calon pejabat hanya menjadi hak panitia seleksi untuk dilaporkan ke pejabat berwenang selanjutnya diajukan kepada pejabat pembina kepegawaian untuk dipilih 1 (satu) orang dari 3 (tiga) nama.

Pengajuan 3 (tiga) nama oleh pejabat berwenang ke pejabat pembina kepegawaian sesuai dengan Peraturan Menteri Pendayagunaan Aparatur Negara dan Reformasi Birokrasi Nomor 13 Tahun 2014 pada poin II tata cara seleksi pengisian jabatan pimpinan tinggi. Pada point tersebut dijelaskan panitia seleksi menyampaikan hasil penilaian jabatan tinggi pratama (setara dengan eselon IIa dan IIb) dan memilih sebanyak 3 (tiga) calon sesuai urutan nilai tertinggi untuk disampaikan kepada pejabat yang berwenang. Pejabat yang berwenang mengusulkan 3 (tiga) nama calon yang telah dipilih panitia seleksi kepada pejabat pembina kepegawaian (menteri/pimpinan lembaga/gubernur/bupati/walikota).

Kemudian UndangUndang Nomor 5 Tahun 2014 tenta Aparatur Sipil Negara pasal 115 dijelaskan Pejabat Pembina Kepegawaian memilih 1 (satu) dari 3 (tiga) nama calon sebagaimana dimaksud pada ayat (3) untuk ditetapkan dan dilantik sebagai pejabat pimpinan tinggi pratama.

Berdasarkan hal tersebut, dapat disimpulkan bahwa pelaksanaan seleksi JPTP pada tahap ini belum memenuhi standar asas transparansi sesuai harapan dari pelaksanaan merit system. Hal ini disebabkan tidak didukung dengan kebijakan yang mengatur secara spesifik tentang asas transparansi dalam mekanisme dan tata cara proses seleksi JPTP khususnya dalam penetapan bobot nilai dan tahap penetapan calon pejabat. Oleh karena itu, untuk mencapai tujuan pelaksanaan seleksi terbuka yang tertuang dalam Peraturan Menteri Pendayagunaan Aparatur Negara dan Reformasi Birokrasi Republik Indonesia Nomor 13 Tahun 2014 yakni terselenggaranya seleksi calon pejabat pimpinan tinggi utama, madya dan pratama yang transparan, objektif, kompetitif dan akuntabel, pemberian bobot dan hasil penilaian setiap tahapan pelaksanaan seleksi terbuka pimpinan tinggi pratama harus diatur lebih rinci dalam peraturan pemerintah dan atau keputusan komisi aparatur sipil negara (KASN), sehingga menjadi dasar bagi daerah dalam melaksanakan seleksi.

Hal ini sesuai dengan pandangan Herman (dalam Afriyanto dan Prasojo, 2020) menyatakan kerangka kebijakan peraturan perundang-undangan, lembaga otoritas pengelola kepegawaian, kemampuan sistem manajemen SDM, dan lingkungan merupakan faktor yang menjadi penghambat dalam penerapa meritokrasi untuk pengisian jabatan instansi 
pemerintah. Faktor ini sekaligus juga sebagai prasyarat (prerequisite) yang diperlukan untuk mendukung keberhasilan penerapan meritokrasi dalam pengisian jabatan negeri sipil. Keberhasilan maupun kegagalan meritokrasi pada dasarnya ditentukan oleh sejauh mana prasyarat ini dipenuhi.

\section{Kesimpulan}

Reformasi birokrasi melalui promosi JPTP secara terbuka di Kabupaten Kolaka dan di Kota Kendari Provinsi Sulawesi Tenggara belum sepenuhnya menerapkan aspek transparansi dalam setiap tahapan seleksi. Tahap lamaran, penilaian dan pilihan, serta tahap penetapan belum menghapuskan ketidakadilan, subyektifitas dan "balas budi politik" untuk melahirkan pejabat yang memiliki kompetensi dan professional dibidangnya. Pada tahap lamaran, kurangnya minat pegawai yang mendaftar mengisi lowongan JPTP. Pegawai menilai pelaksanaan JPTP hanya sebagai pemenuhan aturan karena pejabat yang akan menduduki jabatan sudah dipersiapkan. Tahap penilaian dan pilihan, dinilai kurang obyektif dalam pemberian nilai. Pada tahap ini tidak adanya transparansi bobot nilai atau standar baku sebagian pedoman penilaian sehingga persentase bobot nilai ditentukan panitia seleksi. Kemudian prinsip transparansi belum diterapkan pada tahap penetapan. Peserta seleksi tidak mendapatkan informasi jumlah bobot nilai yang diperoleh karena panitia seleksi hanya mengumumkan nomor urut 3 (tiga) nama calon pejabat berdasarkan abjad bukan berdasarkan nilai tertinggi.

Berdasarkan hal tersebut, maka pelaksanaan promosi jabatan tinggi pratama secara terbuka, perlu dibuat regulasi kebijakan yang dapat mengakomodir asas keterbukaan pada setiap tahapan pelaksanaan hingga penetapan. Kemudian perlu membuat regulasi kebijakan yang mengatur standar baku pemberian bobot nilai pada setiap tahapan pelaksanaan seleksi administrasi, assessment centre, penulisan dan presentase makalah, serta wawancara. Serta penambahan sumber daya manusia pada lembaga Komisi Aparatur Sipil Negara (KASN) perlu dilakukan mengingat tugas KASN yang begitu berat dan cakupan pengawasan yang luas. Jika memungkinkan dibentuk kantor perwakilan di beberapa wilayah di Indonesia untuk memudahkan kerja KASN dalam pengisian JPTP di daerah. Sehingga dapat menghemat anggaran pejabat terkait yang akan mengurus persyaratan baik menjadi pansel atau mengikuti seleksi pengisian JPTP.

\section{Ucapan Terima Kasih}

Universitas Sembilanbelas November Kolaka yang telah membiayai penelitian ini. Juliadin (NIM. D1A114052) dan Hijrah Hidayatullah (NIM. 171010119), Mahasiswa Administrasi Publik yang telah membantu dalam pengumpulan data penelitian.

\section{Daftar Pustaka}

Afrianti, Rian., \& Eko Prasojo. (2020). Analisis Proses Pengisian Jabatan Administrasi Berbasis Merit System di Kementerian Energi dan Sumberdaya Mineral. Refomasi Administrasi. Vol. 7 (1): 17-28.

Azhari (2011). Mereformasi Birokrasi Publik Indonesia: Studi Perbandingan Intervensi Pejabat Politik Terhadap Pejabat Birokrasi di Indonesia dan Malaysia. Yogyakrta, Pustaka Pelajar.

Daniarsiyah, Dida. (2017). Penerapan Sistem Merit Dalam Rekrutmen Terbuka Promosi Jabatan Pimpinan Tinggi ASN (Suatu Pemikiran Kritis Analisis). Civil Service, Vol. II (2): 39-47.

Ernada, S.E. (2005). Challenges to The Modern Concept of Human Rights. J. Sosial-Politika. 6(11): $1-12$.

Haider, Huma. (2019). Merit-based recruitment in the public sector: effectiveness and challenges. Institute of development studies. Intitute of development Studies. 1-23. https:// opendocs.ids.ac.uk/opendocs/handle/20.500.12413/14819, tanggal 4 April 2019. 
Holidin, Defny. (2013). Reformasi Birokrasi dalam Praktik. Jakarta, Kementerian Pendayagunaan Aparatur Negera dan Reformasi Birokrasi.

Kumorotomo, W., \& Ambar Widaningrum. (2010). Reformasi Aparatur Negara ditinjau Kembali. Yogyakarta : Gava Media

Laporan Kinerja Kementerian Pendayagunaan Aparatur Negara dan Reformasi Birokrasi Tahun 2019. www.menpan.go.id. Tanggal 4 April 2019.

Mahmudi. (2015). Manajemen Kinerja Sektor Publik. Edisi Ketiga. Yogyakarta: UPP STIM YKPM.

Miles, M.B, Huberman, A.M, \& Saldana, J. (2014). Qualitative Data Analysis, A Methods Sourcebook. Edition 3. USA: Sage Publications. Terjemahan Tjetjep Rohindi Rohidi, UIPress.

Rafi Yahya, MHD., \& Dyah Mutiarin. (2015). Model Lelang Jabatan di Pemerintah Daera Istimewa Yogyakarta. Jurnal Ilmu Pemerintahan \& Kebijakan Publik Universitas Muhammadiyah Yogyakarta, 2 (2): 288-328.

Sabaruddin, Abdul., \& Achmad Lamo Said. (2020). Collaborative Governance: Pendekatan Pelayanan Publik. Jawa Tengah, CV. Pena Perasada.

Sedarmayanti. (2013). Reformasi Administrasi Publik, Reformasi Birokrasi, dan Kepemimpinan Masa Depan (Mewujudkan Pelayanan Prima dan Kepemerintahan yang Baik). Bandung, PT. Refika Aditama.

Soedarmayanti., \& Resna Dakhi. (2017). Persepsi Mengenai Promosi Jabatan Struktural PNS Perempuan di Pemerintah Kota Gunungsitoli. Jurnal Ilmu Administrasi, Vol XIV (2), 167-184.

Suharman, Edi. (2017). Kewenangan Pejabat Pembina Kepegawaian Dalam Pengisian Jabatan Pimpiman Tinggi Pratama di Daerah Menurut Undang-Undang Nomor 5 Tahun 2014 tentang Aparatur Sipil Negara, IUS, V (2): 220-232.

Sugiyono (2016). Metode Penelitian Administrasi. Bandung. Penerbit Alfabeta.

Suparyadi (2015. Manajemen Sumberdaya Manusia: Menciptakan Keunggulan Bersaing Berbasis Komptensi SDM. Yogyakarta. CV. Andi Offset.

Yahya, Rafi., \& Mutiarin. (2015). Model Lelang Jabatan Di Pemerintah Daerah Daerah, Jurnal Ilmu Pemerintahan \& Kebijakan Publik, 2 (2): 286-329.

Siregar, N.S.S. (2016). Tingkat Kesadaran Masyarakat Nelayan terhadap Pendidikan Anak, Jurnal Ilmu Pemerintahan dan Sosial Politik UMA, 4 (1): 1-10.

Undang Undang-Undang Republik Indonesia Nomor 5 Tahun 2014 tentang Aparatur Sipil Negara. Peraturan Menteri Pendayagunaan Aparatur Negara dan Reformasi Birokrasi Republik Indonesia

PermenPAN RB Nomor 13 Tahun 2014 tentang Tata Cara Pengisian Jabatan Pimpinan Tinggi Secara Terbuka di Lingkungan Instansi Pemerintah 